\title{
Three new species of the genus Lepechinella (Amphipoda: Gammaridea: Lepechinellidae) collected from Campos Basin slope, RJ, Brazil
}

\author{
DANIELA J.P. SITTROP and CRISTIANA S. SEREJO \\ Universidade Federal do Rio de Janeiro/Museu Nacional, Quinta da Boa Vista, Departamento de Invertebrados, \\ 20940-040, Rio de Janeiro, RJ, Brasil. E-mail: danielasittrop@ hotmail.com
}

\begin{abstract}
SUMMARY: The genus Lepechinella Stebbing, 1908 has a cosmopolitan distribution and includes 28 species. The three new species of the genus described herein were provided from samples collected from the slope of Campos Basin, as part of the Campos Basin deep-sea environmental project. Samples were taken using a box corer between the depths of 700 and 2000 m. Lepechinella hirsuta $\mathrm{n}$. sp. is characterised by the presence of simple setae on the dorsal midline of the body, an anterior tooth and an anterolateral projection on peraeonite 1 ; Lepechinella campensis $\mathrm{n}$. sp. has peraeonite 1 dorsally sinuous and a posterior upright tooth on peraeonites 2 to 7 ; and Lepechinella laurensi $\mathrm{n}$. sp. has peraeonites 1 to 4 dorsally sinuous and a posterior inclined tooth on peraeonites 5 to 7 . This study provides full descriptions of these three new species and an identification key for South Atlantic species of the genus Lepechinella.
\end{abstract}

Keywords: deep sea, Lepechinella, new species, South Atlantic, Campos Basin, Rio de Janeiro, taxonomy.

RESUMEN: TRes NUEVAS ESPECIES DEL GÉNERo LEPECHINELLA (AMPHipoda: GAMMARIDEA: LePECHINELlidAe) COLECTADAS EN El TALUd DE LA BAHÍA DE CAMPos, RJ, BRAZIL. - El género Lepechinella Stebbing, 1908 presenta una distribución cosmopolita y contiene un total de 28 especies. Las tres nuevas especies del género descritas en el presente trabajo provienen de muestras colectadas en el talud de la "Bacia de Campos" como parte del proyecto de estudio del ambiente marino de aguas profundas de la Bahía de Campos. Las muestras fueron obtenidas mediante un box-corer en profundidades comprendidas entre los 700 y 2000 metros. Lepechinella hirsuta n. sp. se caracteriza por la presencia de setas simples en la línea media dorsal del cuerpo, un diente anterior y una proyección anterolateral en lo pereonito 1; Lepechinella campensis n. sp. presenta el pereonito 1 sinuoso dorsalmente y un diente posterior pronunciado en los pereonitos 2 a 7 ; y Lepechinella laurensi $\mathrm{n}$. $\mathrm{sp}$. presenta los pereonitos 1 a 4 dorsalmente sinuosos y un diente posterior pronunciado en los pereonitos 5 a 7 . El presente estudio proporciona las descripciones completas de estas tres especies nuevas además de una clave de identificación para las especies del género Lepechinella del Atlántico Sur.

Palabras clave: mar profundo, Lepechinella, nueva especie, Atlántico Sur, Bacia de Campos, Rio de Janeiro, taxonomía.

\section{INTRODUCTION}

The taxonomic position of the lepechinellid group has changed during the last century. It is now composed of the genera Lepechinella Stebbing, 1908, Lepechinelloides Thurston, 1980, Lepechinellopsis Ledoyer, 1982, and Paralepechinella Pirlot, 193, and is defined as amphipods adapted to living in the deep sea with adaptations appearing as processes on the dorsal midline of the body and elongate appendages. Stebbing (1908) described Lepechinella and placed it within Paramphithoidae Stebbing, 1906 (currently Iphimediidae Boeck, 1871). Some years later, Chevreux (1914) described the second species 
as Dorbanella and placed this new genus within the family Tironidae Stebbing, 1906 (currently Synopiidae Dana, 1855). Schellenberg, 1925 observed that Dorbanella showed no affinities with Tironidae and established the family Dorbanellidae to receive this genus. Schellenberg (1926) considered Dorbanella as a junior synonym of Lepechinella. However, this author erroneously established the family Lepechinellidae to locate the species of these genera, without realising that Dorbanellidae had the priority, according to the International Code of Zoological Nomenclature (International Commission of Zoological Nomenclature, 1999).

Though Schellenberg (1926) had established Lepechinellidae erroneously, the family name must be retained because Schellenberg's decision was made before 1961 and, according to Articles 23.9.1.1. and 23.9.1.2. of the International Commission of Zoological Nomenclature (ICZN, 1999), Lepechinellidae is in prevailing usage and should be maintained.

Fifty-four years later, J.L. Barnard (1970) transferred (and synonymised) the lepechinellid group, composed at that time of Lepechinella and Paralepechinella, to the subfamily Dexamininae Leach, 1714 within the family Dexaminidae Leach, 1814, and this classification was followed in J.L. Barnard (1973), Ledoyer (1982) and J.L. Barnard and Karaman (1991).

Bousfield and Kendall (1994) proposed a new classification, in which the lepechinellid group is enclosed in the subfamily Lepechinellinae Bousfield and Kendall, 1994 within Atylidae Sars, 1882. However, this classification involves some problems. Even with the current composition, the lepechinellid group has many characters not shared with the other genera also included in Atylidae, such as the shape and length of the peraeopods, and the shape of the oostegites and uropod 3. Based on these characters, Andres and Brandt (2001) considered the lepechinellid group as a family, thus revalidating the status of Lepechinellidae, and these authors also characterised the family by having the distal margin of coxae 1 to 4 pointed distally, pereopods 3 to 7 slender, elongate and similar, and a body with projections on the dorsal midline.

Today, the genus Lepechinella comprises 28 species with a worldwide distribution. Of this total, five species are recorded from the South Atlantic Ocean: Lepechinella auca J.L. Barnard, 1973 (Brazil), Lepechinella cetrata K.H. Barnard, 1932 (South Shetland Islands), Lepechinella chrysostheras Stebbing, 1908,
Lepechinella echinata (Chevreux, 1914), and Lepechinella pangola J.L. Barnard, 1962 (these last three from South Africa). This genus is considered typical of deep waters, since 26 of the 28 species occur from 480 to 6670 metres and they show strong morphological adaptations to living associated with the less compacted substratum of the deep-sea, such as elongation of the appendages, an increase in the number and size of body processes, and a proliferation of setae on the body surfaces (J.L. Barnard, 1973).

The present study describes three new species of Lepechinella and provides a key to the South Atlantic species.

\section{MATERIAL AND METHODS}

The samples were provided from the Campos Basin deep-sea environmental project. Collections were made at Campos Basin, the largest Brazilian oil-bearing area, located in Rio de Janeiro (21 ${ }^{\circ} 48^{\prime} \mathrm{S}$ to $22^{\circ} 48^{\prime}$ S), using N.R. Astrogaroupa during the years 2002 and 2003. Specimens of this study were collected by box corer $(50 \times 50 \times 50 \mathrm{~cm})$ from the continental slope at depths ranging from 700 to $2000 \mathrm{~m}$. The material was fixed in ethanol and is lodged in the collection of Crustacea of the Museu Nacional/ Universidade Federal do Rio de Janeiro (MNRJ).

The DELTA software was used to build a database, from which the identification key was generated.

The setal nomenclature used herein follows Garm, 2004.

The following abbreviations were used: A2, articles 1-3 of peduncle of antenna 2; Hd, head; C1-7, coxae 1-7; Ep1-3, epimera 1-3; Gnt1-2, gnathopods 1-2; LL, lower lip; UL, upper lip; rMd, right mandible; $1 \mathrm{Md}$, left mandible; Mxp, maxilliped; Mx1-2, maxillae 1-2; T, telson; U1-3, uropods 1-3.

\section{SYSTEMATICS}

Family LePECHINELLIDAE Schellenberg, 1926 (1925)

Paramphithoidae Stebbing, 1908: 191, pl. 27.

Tironidae Chevreux, 1914:1, Figs. 1-3.

Dorbanellidae Schellenberg, 1925: 205.

Tironidae (part) K.H. Barnard, 1925: 355

Lepechinellidae Schellenberg, 1926: 344, Fig. 50; K.H. Barnard, 1932: 186, Fig. 114; Dahl, 1959: 235, Fig. 19; Andres and Brandt, 2001 : 79, Figs. 1-11.

Dexaminidae (part) J.L. Barnard, 1970:163; J.L. Barnard, 1973 : 5, Figs. 3-12; Griffiths, 1977: 94, Fig. 1; J.L. Barnard and 
Karaman, 1991: 260, Figs.50 (G, K), 51 (A), 52 (A), 53 (C), $54(\mathrm{G}, \mathrm{I})$; Lepechinellinae Bousfield and Kendall, 1994: 31, Fig. 15.

\section{Genus Lepechinella Stebbing, 1908}

Lepechinella Stebbing, 1908: 191, pl. 27; K.H. Barnard, 1925: 355; Schellenberg, 1926: 344, Fig. 50; K.H. Barnard, 1932: 186, Fig. 114; Dahl, 1959: 237, Fig. 19; J.L. Barnard, 1970:165; J.L. Barnard, 1973: 5, Figs.3-12; Griffiths, 1977: 94, Fig. 1; Thurston, 1980: 70, Figs. 1-8; Gamô, 1981: 17, Fig 2; Ledoyer, 1982: 360, Fig. 136; J.L. Barnard e Karaman, 1991: 268, Figs. 50 (G, K), 51 (A), 52 (A), 54 (G, I);

Dorbanella Chevreux, 1914: 1, Figs.1-3; Schellenberg, 1925: 205.

Diagnosis. Body with projections on the dorsal midline; cephalic tooth divided into two cusps pointed anteriorly; upper lip bilobate; mandible with palp, article 2 of palp of mandible longer than article 3 , incisor process dentate, lacinia mobilis dentate, molar triturative; article 2 of palp of maxilla 1 expanded distally; inner plate of maxilla 2 narrower than outer plate; article 2 of palp of maxilliped longer than articles 1 and 3 combined; peraeopods 3 to 7 slender, all articles elongated, except for article 3 .

\section{Lepechinella campensis n. sp. (Figs 1-3)}

Material examined. Holotype: MNRJ17384, (sex unknown), 5.7 $\mathrm{mm}$, Oceanprof I \#45, 22 ${ }^{\circ} 10^{\prime} 54.4^{\prime \prime} \mathrm{S}$ to $39^{\circ} 52^{\prime} 19.4^{\prime \prime} \mathrm{W}, 1050 \mathrm{~m}$

Etymology. The species is named campensis in reference to its type locality - Bacia de Campos.
Diagnosis. Body with slender setae on dorsal midline; peraeonite 1 dorsally sinuous; peraeonites 2 to 7 with an posterior upright tooth about $0.4-0.5 \mathrm{x}$ as long as corresponding segments; posterior margin of epimera 1 to 3 convex; rostrum about $0.5 \mathrm{x}$ as long as article 1 of antenna 1; first cephalic tooth about $0.6 \mathrm{x}$ as long as rostrum; second cephalic tooth about $0.45 \mathrm{x}$ as long as rostrum; coxa 1 not bifid; coxa 2 asymmetrically bifid; coxa 3 asymmetrically bifid; coxa 4 asymmetrically bifid; coxa 5 projected anterodistally into a pointed lobe; coxa 6 without projections; coxa 7 with acute posterodistal angle; inner ramus of uropod 1 about $0.7 \mathrm{x}$ as long as outer ramus; inner ramus of uropod 2 about $1.17 \mathrm{x}$ as long as outer ramus; inner ramus of uropod 3 about $0.9 \mathrm{x}$ as long as outer ramus.

Description. Holotype, sex unknown, $5.7 \mathrm{~mm}$.

Body. With sparse slender setae on all segments.

Head. Rostrum curved upward, about $0.5 \mathrm{x}$ as long as article 1 of antenna 1; first cephalic tooth about $0.6 \mathrm{x}$ of length of rostrum; second cephalic tooth about $0.45 \mathrm{x}$ as long as rostrum. Antenna 1 . About $0.9 \mathrm{x}$ as long as body and about $1.3 \mathrm{x}$ as long as peduncle of antenna 2; article 3 about $0.65 \mathrm{x}$ as long as article 2; flagellum longer than peduncle. Antenna 2. About $0.7 \mathrm{x}$ as long as body; flagellum longer than peduncle. Upper lip. Asymmetrically bilobate. Mandible. Palp as long as body of mandi-

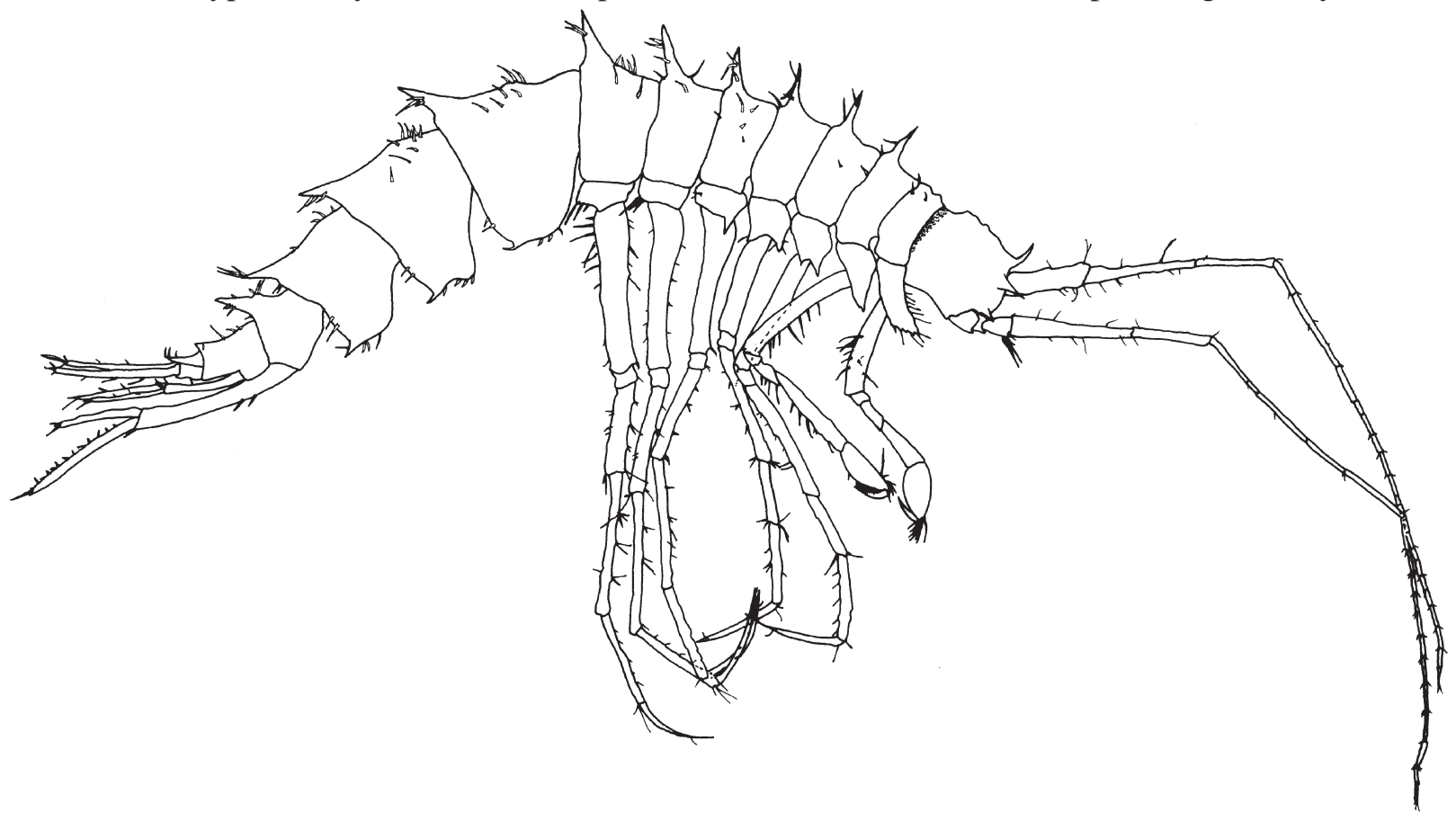

FIG. 1. - Lepechinella campensis n. sp., holotype, sex unknown, 5.7 mm, MNRJ17384, Oceanprof I \#45, 22¹0’54.4”S to 3952’19.4”W. 


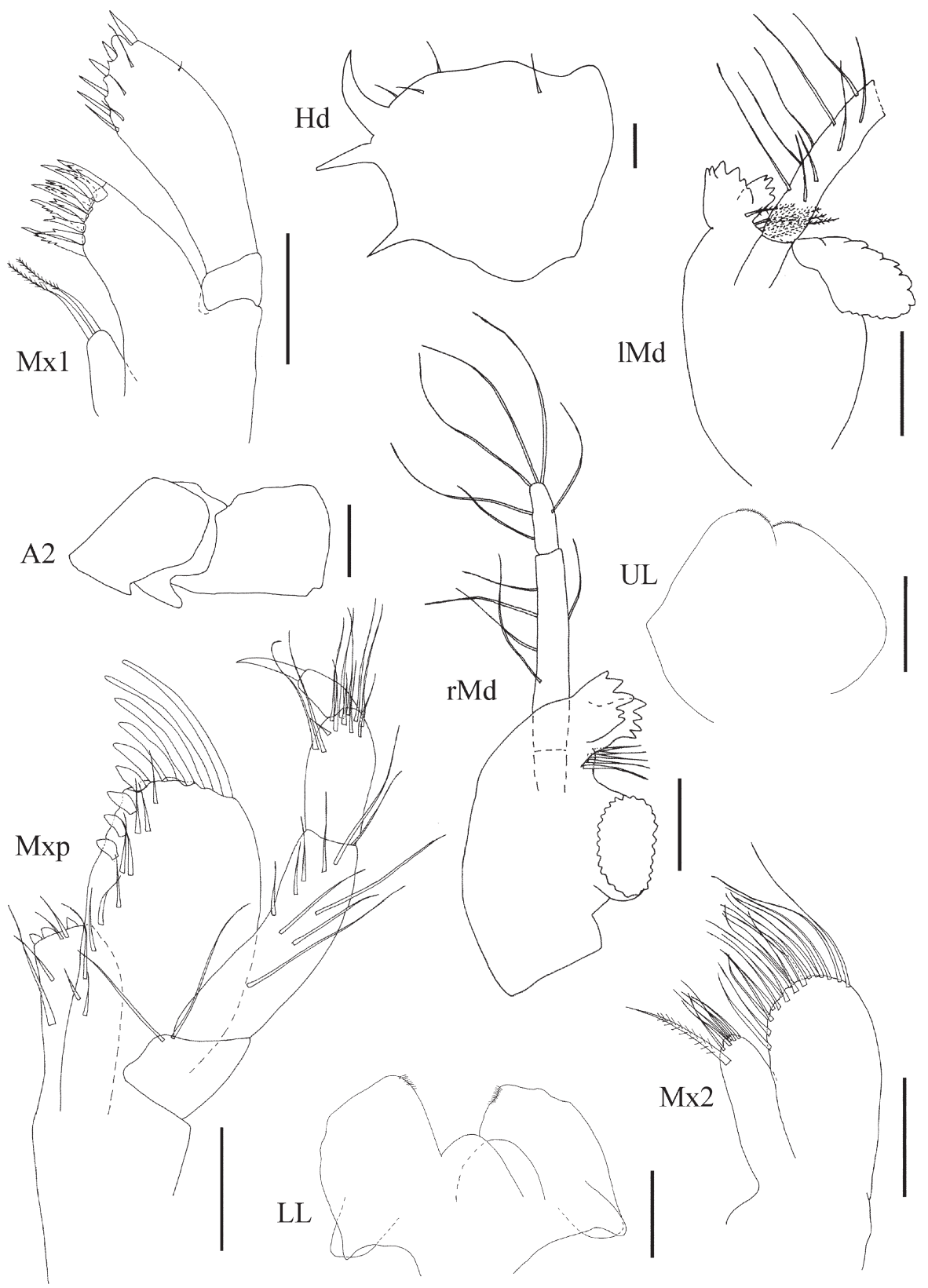

FIG. 2. - Lepechinella campensis n. sp., holotype, sex unknown, 5.7 mm, MNRJ17384, Oceanprof I \#45, 22¹0’54.4”S to 3952’19.4”'W. Scale bars $=0.1 \mathrm{~mm}$.

ble; article 1 of palp about $0.25 \mathrm{x}$ as long as 2 ; article 3 of palp about $0.35 \mathrm{x}$ as long as article 2. Lower lip. Inner lobes broad. Maxilla 1. Inner plate with two pappose setae apically; outer plate with ten robust setae on distal margin; article 2 of palp with six robust setae on distal margin and few facial slender setae. Maxilla 2. Inner and outer plates with slender setae on distal margin; inner plate with a subapically strong pappose seta. Maxilliped. Inner plate with three robust setae on distal margin and facial slender setae; outer plate with nine robust setae on distal margin and facial slender setae.
Peraeon. Segment 1 dorsally sinuous; segments 2 to 7 with an posterior upright tooth about $0.45-0.55$ $\mathrm{x}$ as long as corresponding segment. Gnathopod 1 . Coxa not bifid, distal margin serrate with pappose setae and slender setae; carpus with slender setae distally on anterior and posterior margins; palm oblique, longer than posterior margin of propod. Gnathopod 2. Coxa asymmetrically bifid, distal margin serrate with slender setae; carpus with slender setae; propod suboval; palm oblique, palm and posterior margin of propod subequal in length; palmar angle marked by two robust setae. Peraeopod 3. Coxa asymmetrically 


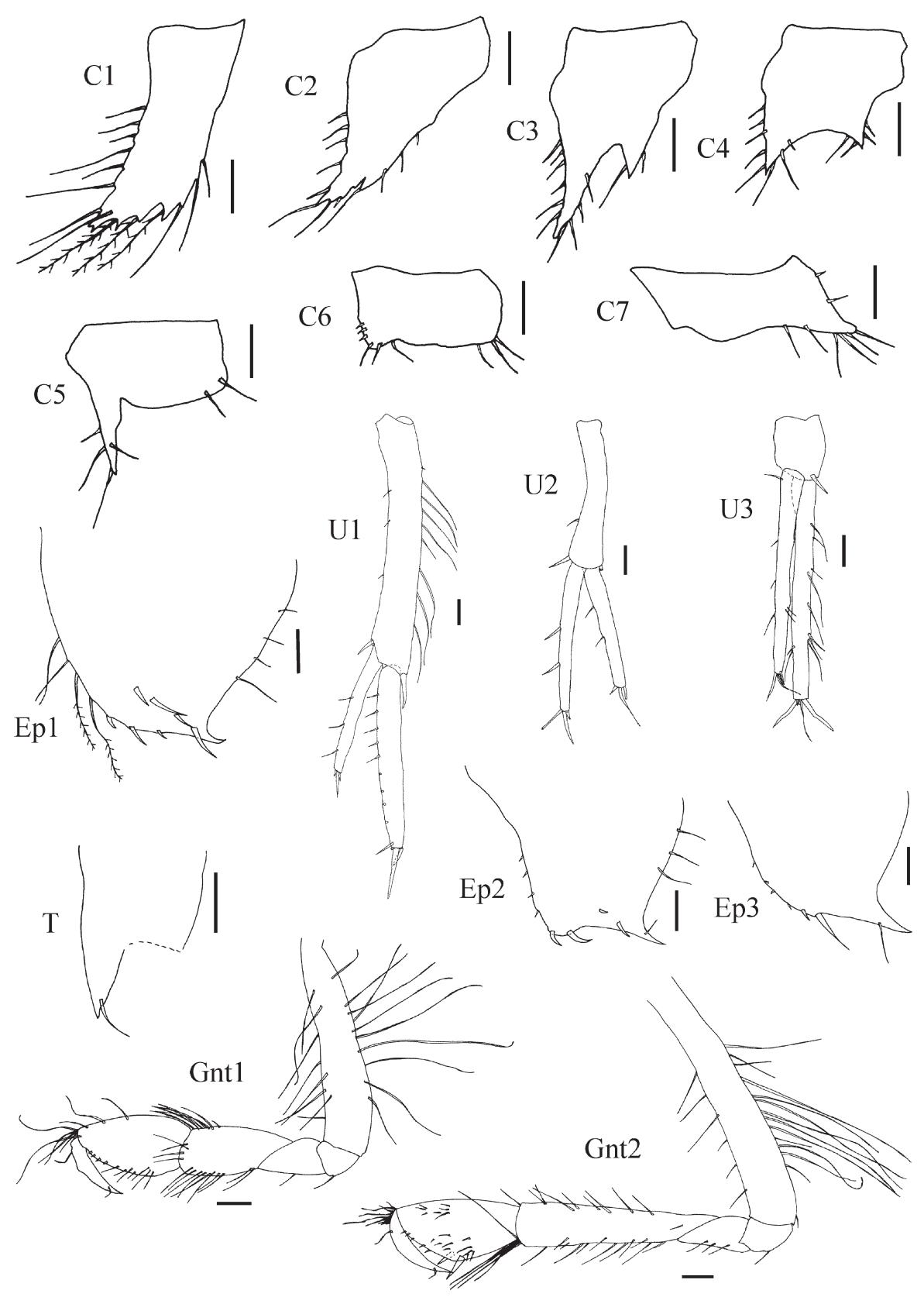

FIG. 3. - Lepechinella campensis n. sp., holotype, sex unknown, 5.7 mm, MNRJ17384, Oceanprof I \#45, 22¹0’54.4”S to 3952’19.4”'W. Scale bars $=0.1 \mathrm{~mm}$.

bifid, margins with slender setae; basis, merus, carpus, propod and dactylus elongated; dactylus with a slender subterminal seta. Peraeopod 4. Coxa asymmetrically bifid, margins with slender setae; articles 2 and 4-7 similar to those of peraeopod 3. Peraeopod 5. Coxa projected anterodistally into a pointed lobe; articles 2 and 4-7 similar to those of peraeopod 3. Peraeopod 6. Coxa without projections; articles 2 and 4-7 similar to those of peraeopod 3. Peraeopod 7. Coxa with acute posterodistal angle; articles 2 and 4-7 similar to those of peraeopod 3 .
Pleon. All segments with a posterior inclined tooth. Epimera. All with posteroventral angle produced backwards; posterior margin of epimeron 1 convex with slender setae, ventral margin with slender setae, pappose setae and robust setae; posterior margin of epimeron 2 convex with slender setae, ventral margin with robust setae; posterior margin of epimeron 3 convex.

Urosome. Segment 1 with a posterior inclined tooth. Uropod 1. Peduncle with a large robust seta beside the insertion of outer ramus and a short robust 
seta beside the insertion of inner ramus; outer ramus about $0.7 \mathrm{x}$ as long as peduncle; inner ramus about $0.70 \mathrm{x}$ as long as outer ramus. Uropod 2. Peduncle with a robust seta beside the insertion of inner ramus; outer ramus about $0.8 \mathrm{x}$ as long as peduncle; inner ramus about $1.17 \mathrm{x}$ as long as outer ramus. Uropod 3. Peduncle very short; inner ramus about $0.9 \mathrm{x}$ as long as outer ramus. Telson. Cleft, longer than broad, lobes divergent, each one with a long slender subterminal seta.

Distribution. Campos Basin, Rio de Janeiro, Brazil. $1050 \mathrm{~m}$.

Remarks. Lepechinella campensis $\mathrm{n}$. sp. is easily distinguished from all other species of the genus by the presence of the unique combination of peraeonite 1 being dorsally sinuous and peraeonites 2 to 7 having one posterior tooth.

Lepechinella hirsuta n. sp. (Figs 4-6)

Material examined. Holotype: MNRJ20523, female, $5.5 \mathrm{~mm}$,

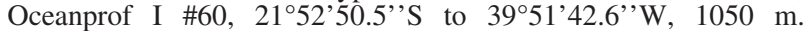
Paratypes: MNRJ16309, Oceanprof I \#60, 21 ${ }^{\circ} 52^{\prime} 50.5^{\prime \prime} \mathrm{S}$ to $39^{\circ} 51^{\prime} 42.6^{\prime} \mathrm{W}, 1050 \mathrm{~m}, 2$ specimens (sex unknown), $2.4 \mathrm{~mm}$ - $3.6 \mathrm{~mm}$; MNRJ16305, Oceanprof I \#45, 22 ${ }^{\circ} 10^{\prime} 54.4^{\prime \prime} \mathrm{S}$ to 3952'19.4”'W, 1050 m, 1 male, 4.9 mm; MNRJ16303, Oceanprof
I 74, $22^{\circ} 27^{\prime} 31.6^{\prime \prime} \mathrm{S}$ to $40^{\circ} 09^{\prime} 23.2^{\prime} \mathrm{W}, 750 \mathrm{~m}, 1$ female, $5.9 \mathrm{~mm}, 1$ specimen (sex unknown), $3.9 \mathrm{~mm}$; MNRJ17386, Oceanprof II \#44, $22^{\circ} 10^{\prime} 43.5^{\prime} \mathrm{S}$ to $39^{\circ} 54^{\prime} 45.0^{\prime} \mathrm{W}, 750 \mathrm{~m}, 1$ specimen (sex unknown), $3.9 \mathrm{~mm}$.

Etymology. Hirsutus, -a, -um, Latin adjective, meaning shaggy. The name alludes to the setae on the dorsal midline of body.

Diagnosis. Body with slender setae on dorsal midline; peraeonite 1 with an anterior tooth and an anterolateral projection, both about $0.1 \mathrm{x}$ as long as corresponding segment; peraeonites 6 and 7 with a posterior inclined tooth about $0.1 \mathrm{x}$ as long as corresponding segments; posterior margin of epimeron 1 nearly straight; posterior margin of epimeron 2 straight; posterior margin of epimeron 3 nearly straight; rostrum about $0.7 \mathrm{x}$ as long as article 1 of antenna 1; first cephalic tooth about $0.15 \mathrm{x}$ as long as rostrum; second cephalic tooth about $0.25 \mathrm{x}$ as long as rostrum; coxa 1 asymmetrically bifid; coxa 2 symmetrically bifid; coxa 3 asymmetrically bifid; coxa 4 asymmetrically bifid; coxa 5 projected anterodistally into a pointed lobe; coxa 6 projected anterodistally into a rounded lobe; coxa 7 with a very short anterodistal projection, posterodistal angle rounded; inner ramus of uropod 1 about $0.75 \mathrm{x}$ as long as outer ra-

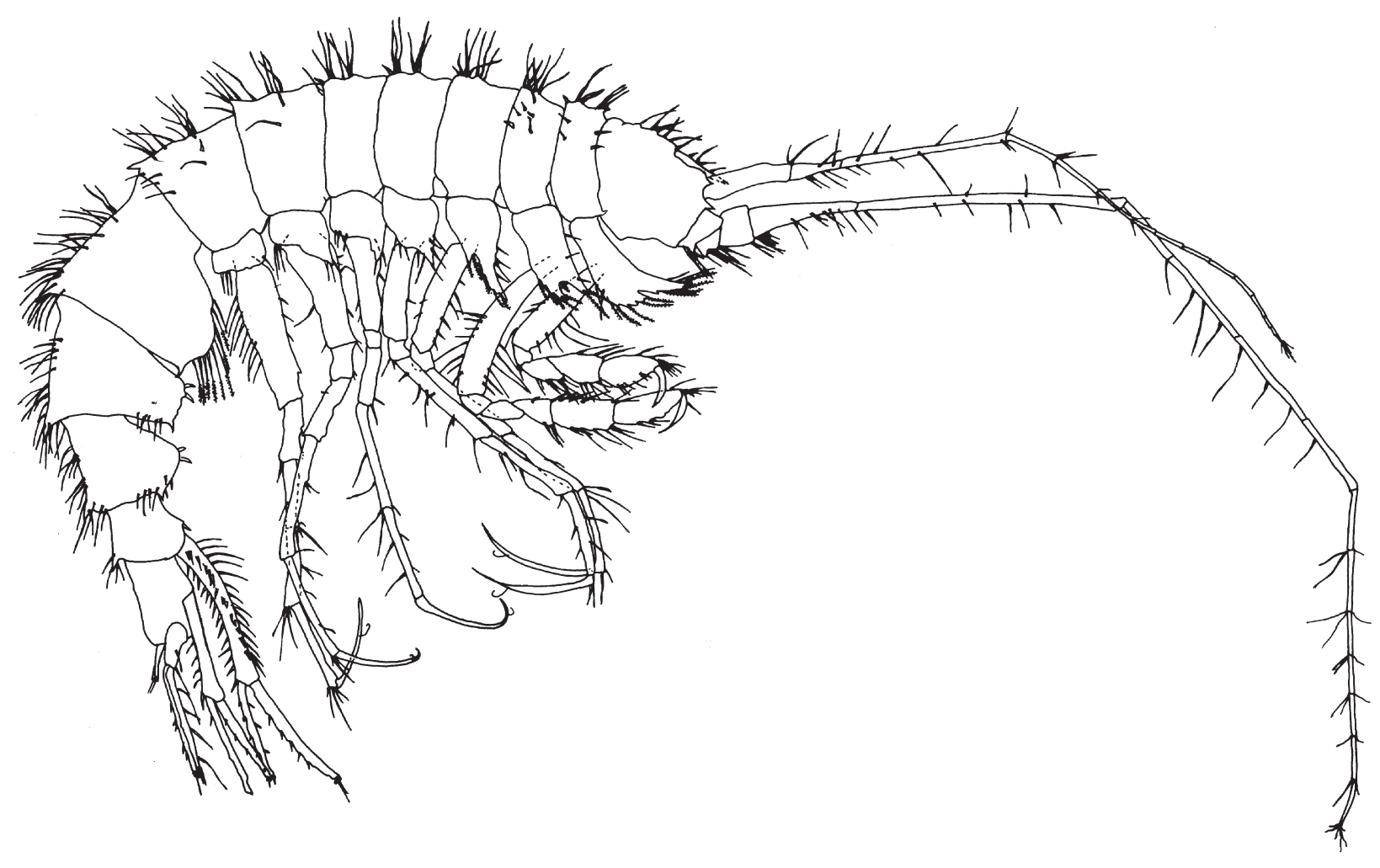

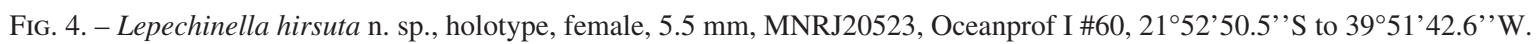




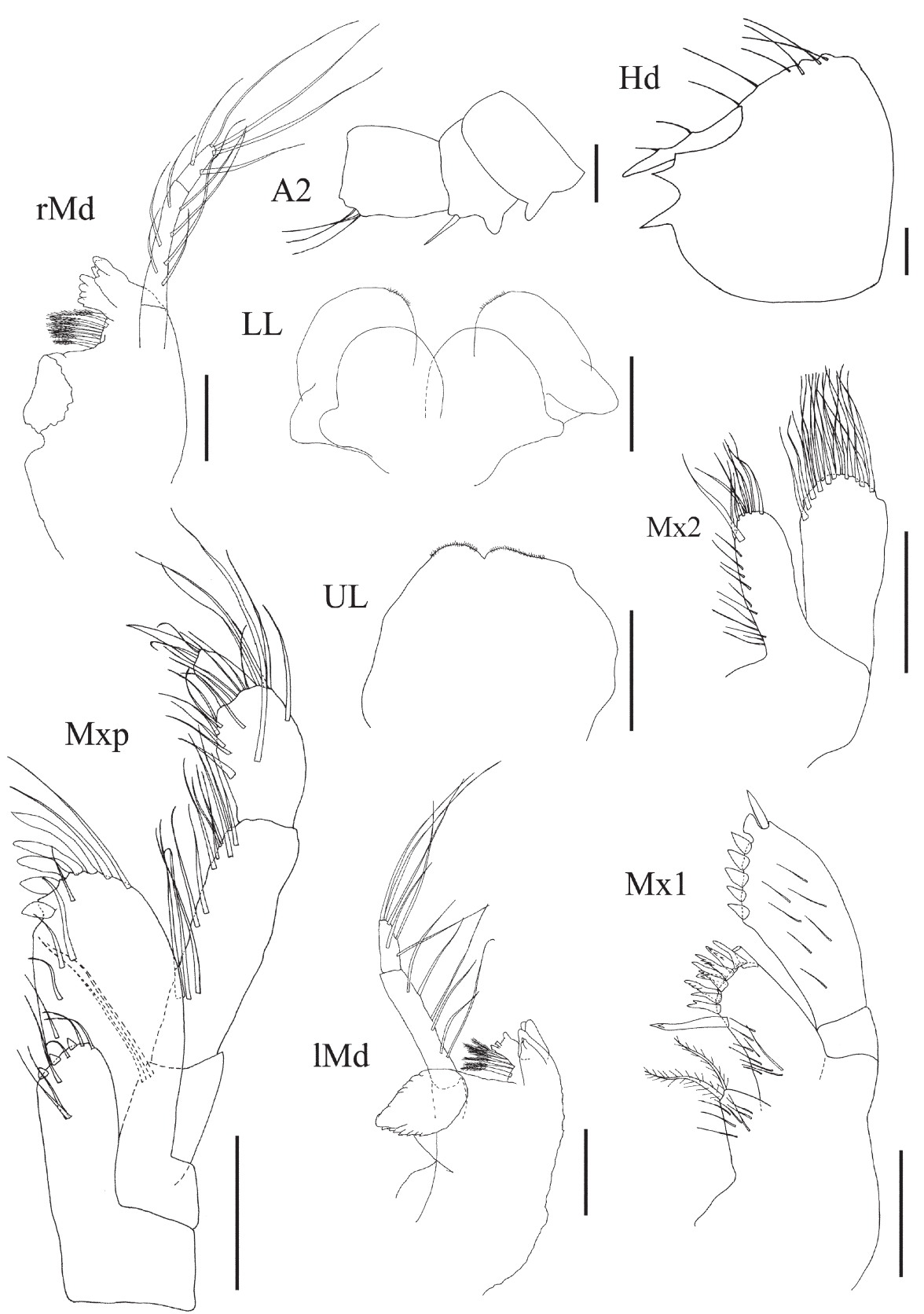

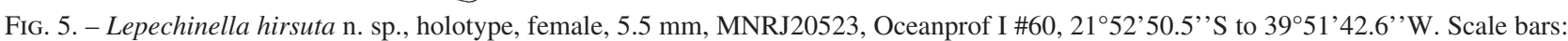
$=0.1 \mathrm{~mm}$.

mus; outer and inner rami of uropod 2 subequal in length; inner ramus of uropod 3 about $0.80 \mathrm{x}$ as long as outer ramus.

Description. Holotype, female, $5.5 \mathrm{~mm}$.

Body. With slender setae on dorsal midline.

Head. See body. Rostrum straight, about $0.7 \mathrm{x}$ as long as article 1 of antenna 1 ; first cephalic tooth about $0.15 \mathrm{x}$ as long as rostrum; second cephalic tooth about $0.25 \mathrm{x}$ as long as rostrum. Antenna 1 . About $0.60 \mathrm{x}$ as long as body and about $1.55 \mathrm{x}$ as long as antenna 2; article 3 longer than articles 1 and 2 combined; flagellum little longer than peduncle. Antenna 2. As long as body; flagellum longer than peduncle. Upper lip. Asymmetrically bilobate. Mandible. Palp as long as body of mandible; article 1 of palp about $0.3 \mathrm{x}$ as long as article 2; article 3 of palp about $0.4 \mathrm{x}$ as long as article 2. Lower lip. Inner lobes broad. Maxilla 1. Inner plate with two pappose setae apically and facial slender setae; outer plate with eleven dentate robust setae on distal margin and facial slender setae; article 2 with six robust setae 


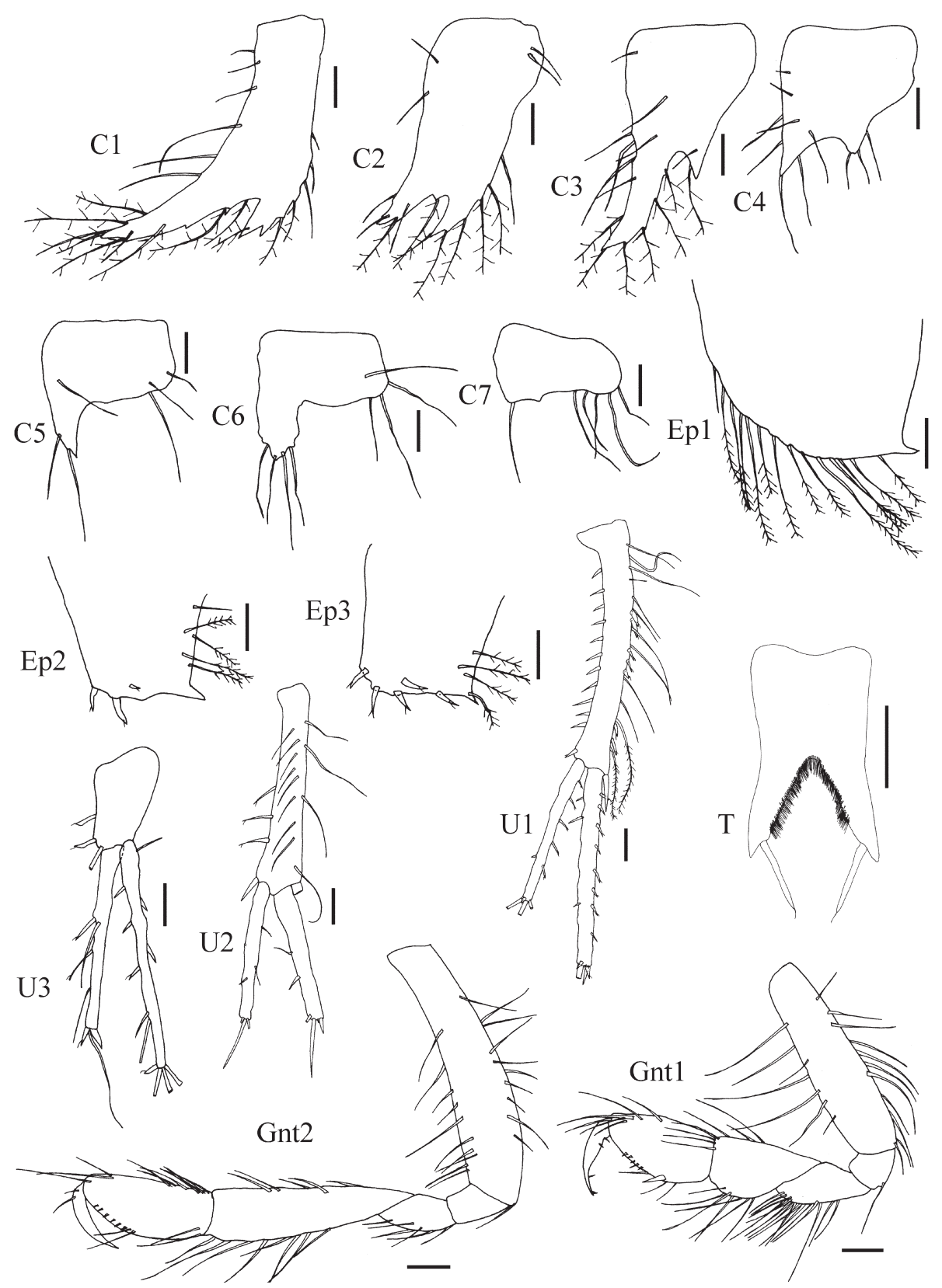

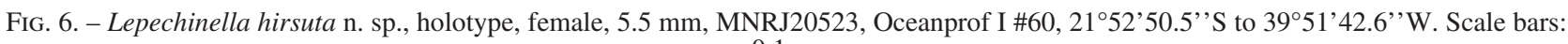
$=0.1 \mathrm{~mm}$.

on distal margin and facial slender setae. Maxilla 2. Inner plate with slender setae on distal margin and a strong seta subapically; outer plate with slender setae on distal margin. Maxilliped. Inner plate with three robust setae on distal margin and two facial slender setae; outer plate with seven robust setae on distal margin and facial slender setae.

Peraeon. Segment 1 with an anterior tooth and an anterolateral projection, both about $0.10 \mathrm{x}$ length of corresponding segment; segments 6 and 7 with a posterior inclined tooth about $0.10 \mathrm{x}$ as long as corresponding segments. Gnathopod 1. Coxa asym- metrically bifid, distal margin serrate with pappose setae; propod suboval; palm oblique, longer than posterior margin of propod; palmar angle marked by a robust seta. Gnathopod 2. Coxa symmetrically bifid, distal margin serrate with pappose setae; propod suboval, palm shorter than posterior margin of propod. Peraeopod 3. Coxa asymmetrically bifid, distal margin serrate with pappose setae; basis, merus, carpus, propod and dactylus elongated; dactylus with a slender subterminal seta. Peraeopod 4. Coxa asymmetrically bifid; articles 2 and 4-7 similar to those of peraeopod 3. Peraeopod 5. Coxa projected 
anterodistally into a pointed lobe; articles 2 and 4-7 similar to those of peraeopod 3. Peraeopod 6. Coxa projected anterodistally into a rounded lobe; articles 2 and 4-7 similar to those of peraeopod 3. Peraeopod 7 . Coxa 7 with a very short anterodistal projection, posterodistal angle rounded; articles 2 and 4-7 similar to those of peraeopod 3 .

Pleon. All segments with a posterior inclined tooth. Epimera. All with posteroventral angle produced backwards; epimeron 1 with posterior margin nearly straight, ventral margin with pappose setae; posterior margin of epimeron 2 straight with pappose setae, ventral margin sinuous with robust setae; posterior margin of epimeron 3 nearly straight with pappose setae, ventral margin with robust setae.

Urosome. Segment 1 with a posterior inclined tooth. Uropod 1. Peduncle with a large robust seta beside the insertion of outer ramus and a short robust seta beside the insertion of inner ramus; outer ramus about $0.85 \mathrm{x}$ as long as peduncle; inner ramus about $0.8 \mathrm{x}$ as long as outer ramus. Uropod 2. Peduncle with a large robust seta beside the insertion of outer ramus and a short robust seta beside the insertion of inner ramus; outer ramus subequal in length to inner ramus, about $0.65 \mathrm{x}$ as long as peduncle. Uropod 3 . Peduncle very short; inner ramus about $0.8 \mathrm{x}$ as long as outer ramus, with robust setae on distal margin. Telson. Longer than broad, cleft about $50 \%$ of length; lobes divergent, each one with inner margin with short slender setae and a long robust subterminal seta on inner margin of each lobe.

Variation. The specimens examined show a minor variation in the rostrum shape, which is slightly curved downward in paratypes. According to Thurston (1980), this character cannot be used to distinguish species, since the rostrum of the specimens examined by him showed "gross intraspecific variation in both length and form". Variations in length and form on the cephalic teeth were also observed, particularly on the first one.

Distribution. Campos Basin, Rio de Janeiro, Brazil. $750-1050 \mathrm{~m}$.

Remarks. Lepechinella hirsuta n. sp. is morphologically similar to L. auca due to the presence of a small anterior tooth and an anterolateral projection on peraeonite 1 . The presence of a posterior tooth on peraeonite 7 and the shape of coxae are also characteristics shared by these two species. However,
L. hirsuta n. sp. can be distinguished from L. auca by the straight posterior margin of epimeron 2 , its telson cleft $50 \%$ of length and the inner margin of each lobe with many short slender setae. L. auca has a convex posterior margin of epimeron 2, a straight posterior margin of epimeron 3 , and the telson cleft $67 \%$ of length, with few setae on the inner margin of each lobe.

Despite Barnard (1973) did not mention in $L$. auca the absence of slender setae along the dorsal midline of body, the presence of a setal row on the anterior and posterior margins of coxae 1 to 4 (coxa 4 with setal row only on anterior margin), and on epimera 1 and 2. These characters can be seen in his drawings and can be used to differentiate this species from L. hirsuta n. sp.

Lepechinella laurensi n. sp. (Figs 7-9)

Material examined. Holotype: MNRJ16485, male, $5.7 \mathrm{~mm}$, Oceanprof II \#58, 21 $57^{\circ} 26.8^{\prime \prime S}$ to $39^{\circ} 40^{\prime} 34.0^{\prime \prime} \mathrm{W}, 1950 \mathrm{~m}$. Paratype: MNRJ18320, \# Roncador, 1 female, $5.1 \mathrm{~mm}$.

Etymology. The species is named laurensi in honour of Dr. J. Laurens Barnard and in recognition of his large contribution to the study of the genus Lepechinella.

Diagnosis. Peraeonites 1 to 4 dorsally sinuous; peraeonites 5 to 7 with a posterior inclined tooth about $0.45 \mathrm{x}$ as long as corresponding segments; posterior margin of epimera 1,2 and 3 convex; rostrum about $0.50 \mathrm{x}$ as long as article 1 of antenna 1; first cephalic tooth about $1.3 \mathrm{x}$ as long as rostrum; second cephalic tooth about $0.7 \mathrm{x}$ as long as rostrum; coxa 1 not bifid; coxa 2 not bifid, tapering distally; coxa 3 projected anterodistally into a pointed lobe; coxa 4 symmetrically bifid; coxa 5 and coxa 6 projected anterodistally into a rounded lobe; coxa 7 posterodistal angle rounded; inner ramus of uropod 1 about $0.65 \mathrm{x}$ as long as outer ramus; inner ramus of 2 about $1.35 \mathrm{x}$ as long as outer ramus; inner and outer rami of uropod 3 subequal in length.

Description. Holotype, male, $5.7 \mathrm{~mm}$.

Body. With slender setae on tooth of peraeonites 7, epimeron 1 and urosomite 1.

Head. Rostrum nearly straight, about $0.5 \mathrm{x}$ as long as article 1 of antenna 1 ; first cephalic tooth about $1.3 \mathrm{x}$ as long as rostrum; second cephalic tooth about $0.7 \mathrm{x}$ as long as rostrum. Antenna 1 . About $0.65 \mathrm{x}$ as long as body and about $1.6 \mathrm{x}$ as long as peduncle of 


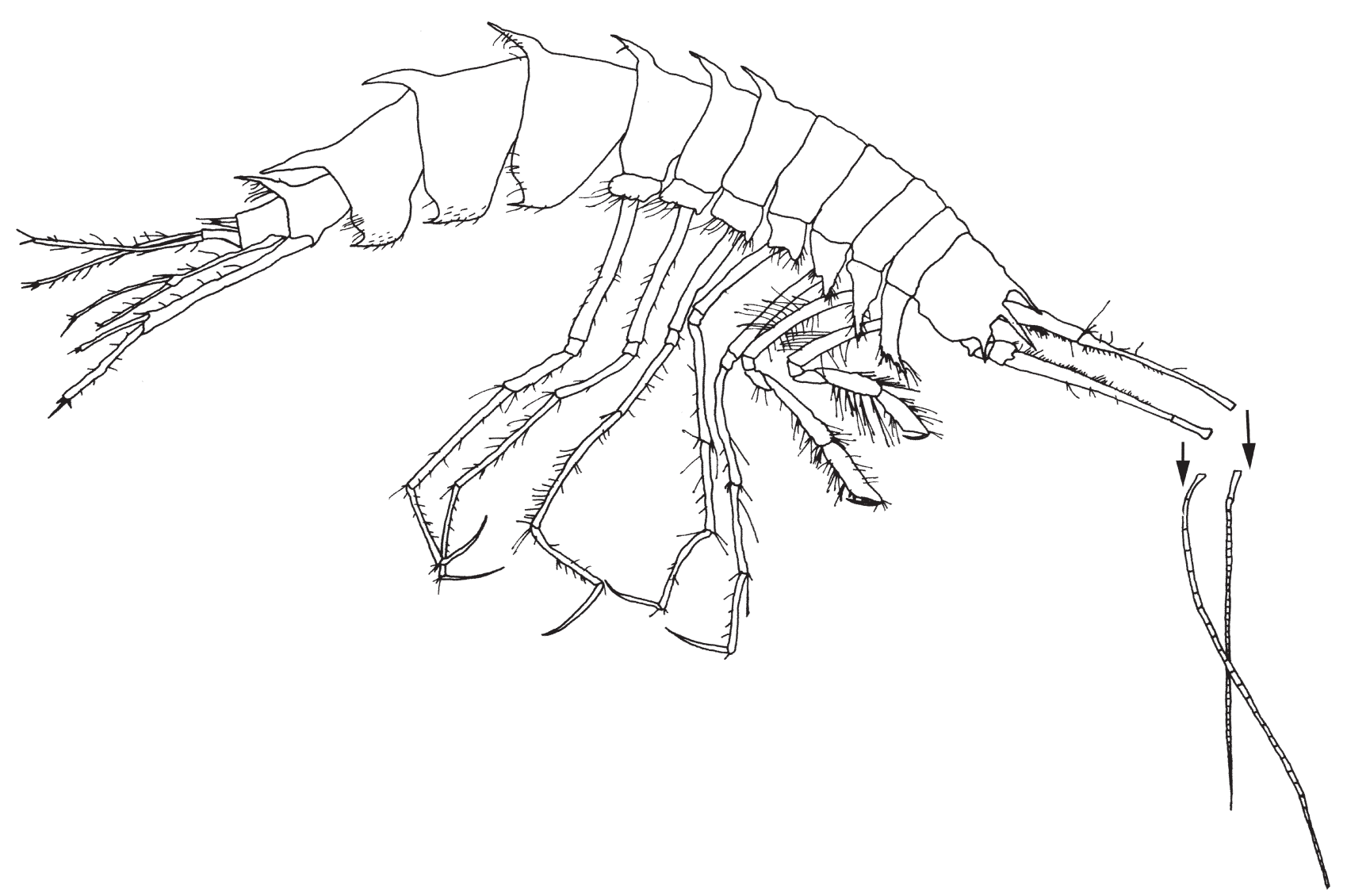

FIG. 7. - Lepechinella laurensi n. sp., holotype, male, 5.7 mm, MNRJ16485, Oceanprof II \#58, 2157’26.8”S, 3940’34.0”W.

antenna 2; article 1 about $0.50 \mathrm{x}$ as long as article 2; article 3 about $0.15 \mathrm{x}$ as long as article 2; flagellum longer than peduncle. Antenna 2. About $0.85 \mathrm{x}$ as long as body; flagellum longer than peduncle. Upper lip. Asymmetrically bilobate. Mandible. Palp as long as body of the mandible; article 1 of palp about 0.25 $\mathrm{x}$ as long as article 2; article 3 about $0.4 \mathrm{x}$ as long as article 2. Lower lip. Inner lobes broad. Maxilla 1. Inner plate with two pappose setae apically; outer plate with ten robust setae on distal margin; article 2 of palp with seven robust setae and one strong seta on distal margin and facial slender setae. Maxilla 2. Inner and outer plates with slender setae on distal margin; inner plate with a slender seta subapically. Maxilliped. Inner plate with three robust setae on distal margin and facial slender setae; outer plate with nine robust setae on distal margin and facial slender setae.

Peraeon. Peraeonite 1 to 4 dorsally sinuous; peraeonites 5 to 7 with a posterior inclined tooth about $0.45 \mathrm{x}$ as long as corresponding segment. Gnathopod 1. Coxa not bifid, posterodistal and distal margins serrate with slender setae; propod rectangular; palm oblique, shorter than posterior margin of pro- pod. Gnathopod 2. Coxa not bifid, tapering distally, anterior and posterior margins serrate with slender setae; propod rectangular, palm oblique, shorter than posterior margin of propod. Peraeopod 3. Coxa projected anterodistally into a pointed lobe, anterior and posterior margins with slender setae; basis, merus, carpus, propod and dactylus elongated. Peraeopod 4. Coxa symmetrically bifid, distal margin with slender setae; articles 2 and 4-7 similar to those of peraeopod 3. Peraeopod 5. Coxa projected anterodistally into a rounded lobe, articles 2 and 4-7 similar to those of peraeopod 3. Peraeopod 6. Coxa projected anterodistally into a rounded lobe, distal margin with slender setae; articles 2 and 4-7 similar to those of peraeopod 3. Peraeopod 7. Coxa with posterodistal angle rounded, distal margin with slender setae; articles 2 and 4-7 similar to those of peraeopod 3.

Pleon. All segments with a posterior inclined tooth. Epimera. All with posteroventral angle produced backwards; posterior margins of epimera 1, 2 and 3 convex, ventral margins of epimera with slender setae.

Urosome. Segment 1 with a posterior inclined tooth. Uropod 1. Peduncle with a large robust seta 


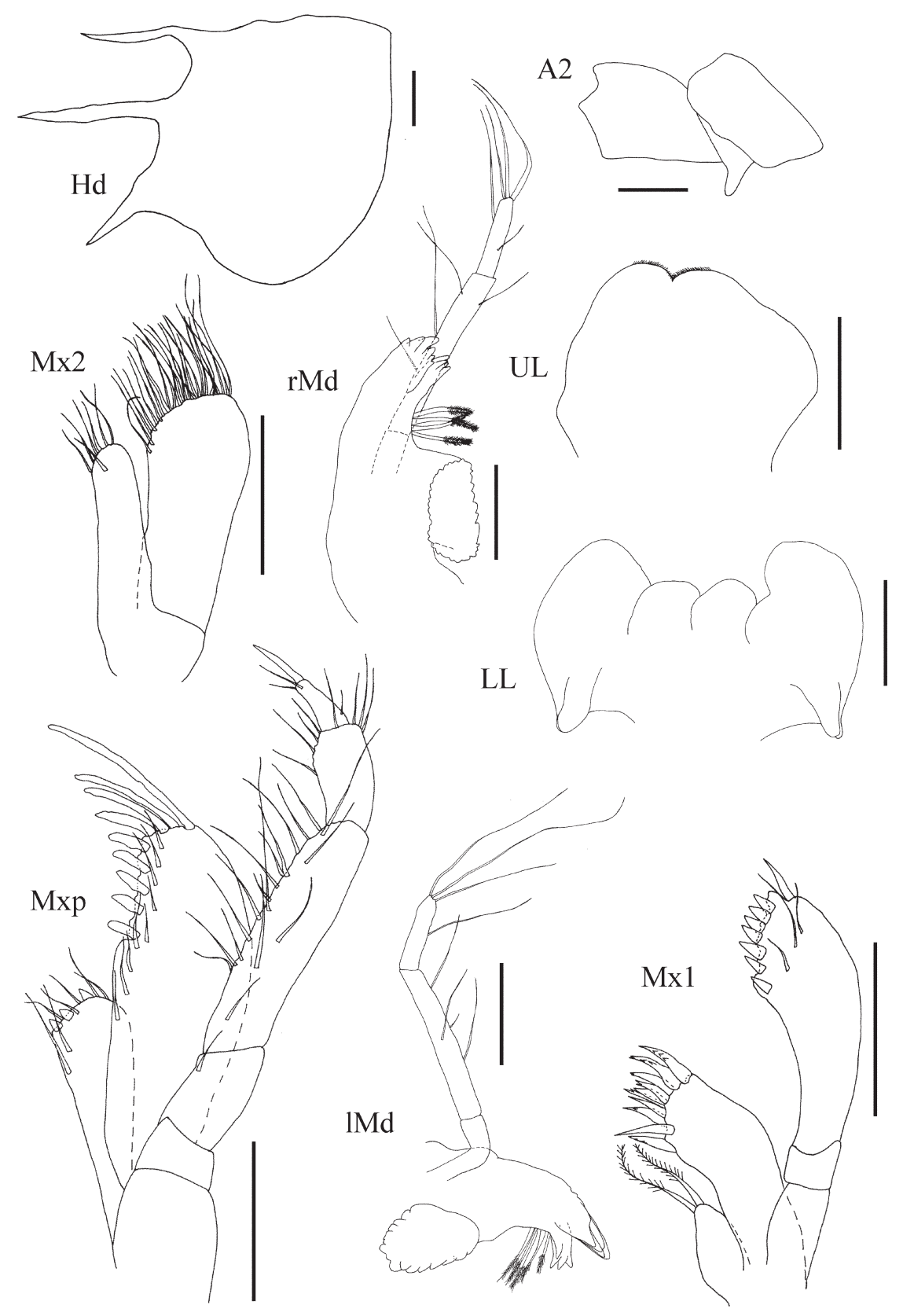

FIG. 8. - Lepechinella laurensi n. sp., holotype, male, 5.7 mm, MNRJ16485, Oceanprof II \#58, 2157’26.8”S, 3940’34.0”W. Scale bars = $0.1 \mathrm{~mm}$.

beside insertion of outer ramus and a short robust seta beside insertion of inner ramus; outer ramus about $0.68 \mathrm{x}$ as long as peduncle; inner ramus about 0.65 $\mathrm{x}$ as long as outer ramus. Uropod 2. Peduncle with a robust seta beside the insertion of inner ramus; outer ramus about $0.7 \mathrm{x}$ as long as peduncle; inner ramus about $1.35 \mathrm{x}$ as long as outer ramus. Uropod 3. Peduncle very short; outer ramus subequal in length to inner ramus. Telson. Longer than broad, cleft about $42 \%$ of length, inner margin of each lobe with short slender setae and a long subterminal slender seta.
Variation. The examined female had the rostrum curved upward and the first cephalic tooth curved downward. However, these are not sexual dimorphism characteristics but individual variations, as seen in L. hirsuta $\mathrm{n}$. sp. The sexual dimorphism in Lepechinella is seen on dorsal teeth of body, which tend to be rather slender and upstanding in females and juveniles males. Adult males can be recognised by more robust and decumbent teeth along the dorsal midline of body (Thurston, 1980), although this variation has not been observed in L. laurensi. 


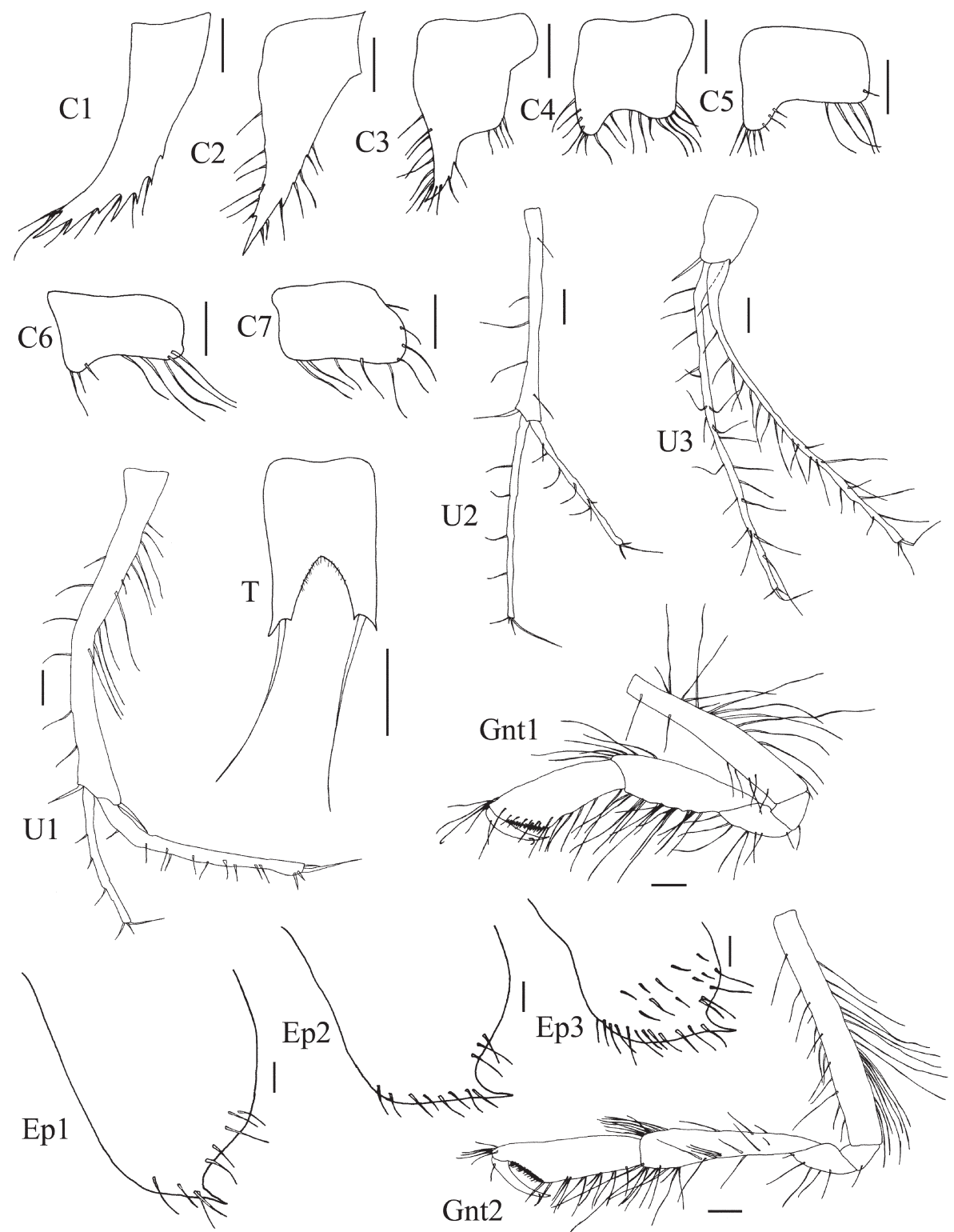

FIG. 9. - Lepechinella laurensi n. sp., holotype, male, 5.7 mm, MNRJ16485, Oceanprof II \#58, 2157’26.8”S, 3940’34.0”W. Scale bars = $0.1 \mathrm{~mm}$.

Remarks. Lepechinella laurensi $\mathrm{n}$. $\mathrm{sp}$. is close to Lepechinella ultraabyssalis Birstein and Vinogradova, 1960 due to the dorsally sinuous peraeonites 1 to 4 , a posterior tooth on peraeonites 5 to 7 , and a convex posterior margin of the epimera. However, $L$. laurensi $\mathrm{n}$. sp. is distinguished from L. ultraabyssalis by the shape of coxae 5 and 6 , which are projected anterodistally in one lobe, while in L. ultraabyssalis the coxae are bifid.

\section{Key to Lepechinella species of South Atlantic}

1. Peraeonite 1 with one anterior dorsal tooth and one anterolateral projection
Lepechinella hirsuta $\mathrm{n}$. sp.

- Peraeonite 1 with two dorsal tooth ................. 2

- Peraeonite 1 dorsally sinuous ......................... 4

2(1). Coxae 1 and 2 not bifid; peraeonites 6 and 7 with a dorsal tooth; epimera 1 to 3 with one dorsal tooth .3

- Coxa 2 projected anterodistally into a pointed lobe; Coxa 1 symmetrically bifid; peraeonites 6 and 7 with two dorsal teeth; epimera 1 to 3 with three dorsal teeth

.....Lepechinella chrysostheras Stebbing, 1908

3(2). Coxae 3 and 4 asymmetrically bifid; uropods 2 and 3 inner ramus $50 \%$ of length of outer ramus 
Lepechinella echinata (Chevreux, 1914)

- Coxae 3 and 4 symmetrically bifid; uropods 2 and 3 inner ramus subequal in length to outer ramus

Lepechinella pangola J.L. Barnard, 1962

4(1). Coxa 4 asymmetrically bifid 5

- Coxa 4 symmetrically bifid

- $\quad$ Coxa 4 not bifid Lepechinella laurensi $\mathrm{n}$. sp. Lepechinella cetrata K.H. Barnard, 1932

5(4).Coxa 2 asymmetrically bifid; Coxa 1 and 6 not bifid; coxa 7 with posterodistal angle acute...... Lepechinella campensis $\mathrm{n}$. sp.

- Coxa 2 symmetrically bifid; coxa 1 asymmetrically bifid; coxa 6 with blunt anteroventral lobe; coxa 7 with posterodistal angle rounded Lepechinella auca J.L. Barnard, 1973

\section{ACKNOWLEDGEMENTS}

The Conselho Nacional de Desenvolvimento Científico e Tecnológico $(\mathrm{CNPq})$ is thanked for the fellowship of the first author and PETROBRAS (Petróleo Brasileiro S.A.) is thanked for the material collected. We also wish to thank M. Valério-Berardo and A. Kury for many suggestions to the manuscript and A. Pérez Gonzáles for translating the abstract.

\section{REFERENCES}

Andres, H.G. and A. Brandt. - 2001. Lepechinellid genera Paralepechinella Pirlot, 1933 and Lepechinelloides Thurston, 1980: first records from Antarctica (Crustacea: Amphipoda. Mitt. Zool. Mus. Inst., 98: 77-97.

Barnard, J.L. - 1962. South Atlantic abyssal Amphipods collected by R. V. Vema. Abyssal Crustacea, Vema Research Series, 1: $1-78$.
Barnard, J.L. - 1970. The identity of Dexamonica and Prinassus with a revision of Dexaminidae (Amphipoda). Crustac. Int. J. Crustac. Res., 19(2): 162-180.

Barnard, J.L. - 1973. Deep-sea Amphipoda of the genus Lepechinella (Crustacea). Smithson. Contrib. Zool., 133: 1-31.

Barnard, J.L. and G.S. Karaman. - 1991. The families and genera of marine gammaridean Amphipoda (except marine gammaroids). Part 1. Rec. Aust. Mus., 13 (Suppl.): 1-417.

Barnard, K.H. - 1925. Contributions to the crustacean fauna of South Africa, No. 8. Further additions to the list of Amphipoda. Ann. S. Afr. Mus., 20 (5): 319-380.

Barnard, K.H. - 1932. Amphipoda. Discovery Rep., 5: 1-326.

Bousfield, E.L. and A. Kendall. - 1994. The Amphipoda superfamily Dexaminoidea on the North American Pacific coast, families Atylidae and Dexaminidae: systematics and distributional ecology. Amphipacifica, 1(3): 3-66.

Chevreux, E. - 1914. Diagnoses d'Amphipodes nouveux provenant des campagnes de la Princesse-Alice dans l'Atlantique nord. Bull. Inst. Oceanogr., 296: 1-4.

Dahl, E. - 1959. Amphipoda from depths exceeding 6000 meters. Galathea Rep., 1: 211-241.

Gamô, S. - 1981. A new deep-sea Amphipoda, Lepechinella sagamiensis sp. nov. from Sagami Bay. Proc. Jap. Syst. Zool., 20: $16-20$.

Garm, A. - 2004. Revising the definition of the crustacean seta and setal classification systems based on examinations of the mouthparts setae of seven species of decapods. Zool. J. Linn. Soc., 142: 233-252.

Griffiths, C.L. - 1977. Deep-sea amphipods from west of cape point, South Africa. Ann. S. Afr. Mus., 73(4): 93-104.

International Commission of Zoological Nomenclature. - 1999. Interntional Code of Zoological Nomenclature. London.

Ledoyer, M. - 1982. Crustacés amphipodes gammariens familles des Acanthonotozomatidae à Gammaridae. Faune Madag., 59(1): 1-598.

Pirlot, J.M. - 1933. Les Amphipodes de léxpedition du Siboga. Deuxième partie. Les amphipodes gammarides II : Les amphipode de la mer profonde. 1 (Lysianassidae, Stegocephalidae, Stenothoide, Pleustidae, Lepechinellidae). Siboga Exped.. Mon., 33c: 115-167.

Schellenberg, A. - 1925. Die Gammariden Spitzbergens nebst einer Übersicht der von Römer and Schaudinn 1898 im nördlichen Eismeer gesammelten Arten. Mitt. Zool. Mus. Berlin, 11 (2): 195-231.

Schellenberg, A. - 1926. Die gammariden der deutschen SüdpolarExpedition 1901-1903. Deutsch Südpolar-Exped., 18: 235-414.

Stebbing, M.A. - 1908. On two new species of Northern Amphipoda. Zool. J. Linn. Soc., 30: 191-197.

Thurston, M.H. - 1980. Abyssal benthic Amphipoda (Crustacea) from the East Iceland Basin. Bull. Br. Mus. Nat. Hist. (Zool.), 38(1): 69-87.

Scient. ed.: M.P. Olivar.

Received June 10, 2008. Accepted November 25, 2008.

Published online April 6, 2009. 